\title{
FAKTOR-FAKTOR YANG MEMPENGARUHI PENDIDIKAN AGAMA HINDU DALAM MENYIKAPI PELAKSANAAN UJIAN SEKOLAH BERSTANDAR NASIONAL DI SMA NEGERI 2 BANAMA TINGANG KABUPATEN PULANG PISAU
}

\author{
I Made Paramarta \\ Institut Agama Hindu Negeri Tampung Penyang Palangkaraya \\ bawiayahfda@gmail.com
}

\begin{abstract}
Riwayat Jurnal
Artikel diterima : -

Artikel direvisi : :

Artikel disetujui :-
\end{abstract}

\begin{abstract}
Abstrak
Seiring dengan perkembangan zaman, tingkat pendidikan pada masyarakat mengalami peningkatan. Oleh sebab itu pendidikan pada tingkat menengah atas dipandang penting bagi masyarakat. Pendidikan dengan produknya berupa jasa pendidikan merupakan lembaga yang berfungsi sebagai tempat untuk menyelenggarakan pendidikan atau pengajaran, penelitian dan pengabdian pada masyarakat. Pihak-pihak yang selalu dapat melakukan perubahan menuju kepada kemajuan dapat dipastikan menjadi pemenang dalam sebuah persaingan. Perlunya sikap yang tegas dan serius guna menanggulangi faktor-faktor yang kurang positif serta menghambat kemajuan dunia pendidikan di tingkat menengah atas. Kurikulum merupakan seperangkat rencana dan pengaturan tentang isi dan bahan pelajaran serta cara yang digunakan sebagai pedoman penyelenggaraan kegiatan belajarmengajar di sekolah. Pengertian ini menggaris-bawahi adanya 4 (empat) komponen pokok dalam kurikulum, yaitu tujuan, isi/bahan, organisasi dan strategi. Secara umum, kurikulum 2013 bertujuan untuk mempersiapkan manusia Indonesia agar memiliki kemampuan hidup sebagai pribadi dan warga negara yang beriman, produktif, kreatif, inovatif, dan afektif serta mampu berkontribusi pada kehidupan bermasyarakat, berbangsa, bernegara, dan peradaban dunia. Pendidikan dalam konteks ini yang dimaksud adalah seperti yang dinyatakan dalam Undang-undang Republik Indonesia Nomor 20 Tahun 2003, yakni dengan penekanan sebagai usaha sadar yang terencana dalam mengembangkan potensi anak didik (Depdiknas, 2003:6). Pendidikan agama Hindu mempunyai peran yang sangat strategis dalam pengembangan sistem pendidikan nasional di Indonesia dan peningkatan sumber daya manusia. Oleh karena itu untuk mengetahui mutu pendidikan agama Hindu yang dilaksanakan di sekolah perlu dilakukan evaluasi yang menyeluruh terhadap hasil pembelajaran peserta didik melalui Ujian Sekolah Berstandar Nasional.
\end{abstract}

Kata Kunci: Faktor, Pendidikan Hindu, Ujian Sekolah Berstandar Nasional. 


\section{PENDAHULUAN}

Sekolah merupakan salah satu tempat dimana siswa mendapatkan ilmu secara formal. Sekolah bukan hanya tempat menimba ilmu, tetapi juga sebagai tempat berkumpul, bermain dan berbagai keceriaan antara siswa yang satu dengan siswa yang lainnya sehingga terjadi interaksi di dalamnya. Sekolah juga merupakan tempat dimana kegiatan belajar mengajar berlangsung dan tempat terjadinya interaksi antara guru dan murid. Manusia diciptakan oleh Tuhan dengan membawa restu yang merdeka, mempunyai hak dan kebebasan yang telah melekat ada dirinya. Oleh karena itu dalam kehidupan, manusia mempunyai hak untuk hidup, hak bersuara, kebebasan mengemukakan pendapat, dan hak yang lainnya selama kebebasan dan hak tersebut tidak bertentangan dengan norma sosial agama.

Begitu juga dalam kegiatan belajar mengajar, dalam hal ini siswa mempunyai hak dan kebebasan untuk bersuara, berpendapat atau beragumen di dalam kelas yang berkaitan dengan materi pelajaran di kelas. Saat berlangsungnya Kegiatan Belajar Mengajar (KBM) seharusnya yang aktif bukanlah gurunya saja, dimana siswa hanya dianggap sebagai suatu benda yang pasif, yang hanya mendengarkan dan mematuhi apa yang disampaikan oleh guru.

Agama merupakan hal yang sangat urgen dalam kehidupan, baik itu anak-anak, remaja, dewasa ataupun orang tua. Jika seseorang tidak memahami ajaran agama dengan baik, maka tak heran jika perbuatan dan perilakunya sangat jauh dari prilaku yang baik. Apabila seorang manusia tidak dibekali ilmu agama sejak dini maka di masa mendatang akan sulit untuk mempelajari mulai dari awal, namun itu tidak bisa digeneralisir tapi pada umumnya memang seperti itu. Apalagi remaja, kata ini tidak asing bagi setiap insan karena pada masa inilah pembentukan karakter dari setiap manusia ditentukan. Remaja identik dengan kondisi labil dan penuh gejolak baik yang baik maupun yang buruk, tinggal tergantung pemahaman merka masing-masing.

Pada masa inilah berbagai tawaran dan tantangan dihadapkan bagi seseorang peserta didik, apabila dalam pembentukan pemahaman mereka baik dan tertata untuk disiapkan menjadi anak yang bhakti maka tidak akan terlalu khawatir,namun jika arahan itu tidak ada dan kontrol yang kurang maka tidak menutup kemungkinan mereka akan mencoba berbagai hal yang menantang dan cenderung negatif. Oleh karena itu pendidikan agama bagi peserta didik sangatlah penting untuk meluruskan berbagai persepsi yang salah dan negatif bagi peserta didik.Dengan memberikan modal pendidikan agama, tununan dan keimanan dipandang mampu dan perlu guna memberikan suport mental dan spiritual dalam kelangsungan mengarungi hidupnya dimasa mendatang dan selanjutnya yang begitu banyak tangtangan. Ironisnya sebagian sekolah dan pihak tertentu yang bergerak dibidang pendidikan saat ini memberikan ruang pendidikan agama di sekolah yang hanya ada hanya 2 -3 jam 
pelajaran disekolah dasar sampai menengah atas dalam seminggu, 2 Jam untuk proses pembelajaran Kurikulum Tingkat Satuan Pembelajaran (KTSP) dan 3 Jam untuk proses pembelajaran kurikulum 2013 (K13), walaupun disisi lain ada sekolah informal (Pasraman) dan perhatian keluarga akan tetapi kemampuan mereka dalam memahami peserta didikbelumlah pada standar yang ada pada dunia pendidikan. Hal inilah yang perlu diperhatikan tentang kebutuhan pendidikan agama guna mengurangi masalah yang krusial bagi sekolah dalam memberikan bimbingan dan perhatian pada sisi agama. Pendidikan agama adalah sebuah literasi yang membuka karakter dan keterampilan dalam disiplin ilmu umum yang diterapkan pada pembelajaran di Indonesia.

Dalam rangka mewujudkan tujuan pendidikan nasional semua pihak perlu berusaha untuk menciptakan suasana lingkungan yang mendukung baik dari jalur pendidikan formal maupun informal. Pendidikan keluarga sebagai bagian dari pendidikan informal mempunyai peranan yang cukup penting dalam rangka mencerdaskan kehidupan bangsa melalui pengalaman seumur hidup. Sedangkan pembelajaran di sekolah memerlukan suatu iklim pembelajaran yang kondusif dengan pembelajaran iklim yang kondusif yang dimaksud adalah penyediaan sarana dan prasarana yang menunjang proses belajar mengajar. Kita ketahui berhasil tidaknya suatu usaha atau kegiatan banyak tergantung pada tujuan yang hendak dicapai oleh orang atau lembaga yang melaksanakannya.
Undang-undang Nomor 20

tahun 2003 tentang Sistem Pendidikan Nasional Bab XVI pasal 57 ayat (1) menyatakan bahwa evaluasi dilaksanakan dalam rangka pengendalian mutu pendidikan secara nasional sebagai bentuk akuntabilitas penyelenggara pendidikan kepada pihak-pihak yang berkepentingan.Selanjutnya Peraturan Pemerintah No. 55 tahun 2007 mengamanatkan bahwa pendidikan agama merupakan tanggung jawab Kementerian Agama sebagaimana yang dinyatakan pada pasal 3 ayat (1) bahwa setiap satuan pendidikan pada semua jalur, jenis, dan jenjang pendidikan wajib menyelenggarakan pendidikan agama, dan ayat (2) bahwa pengelolaan pendidikan agama dilaksanakan oleh Menteri Agama.Sejalan dengan itu, Peraturan Menteri Agama RI. No. 16 tahun 2010 tentang Pengelolaan pendidikan Agama pada sekolah, pada Bab IX Pasal 26 ayat (1) menegaskan bahwa penilaian hasil belajar pendidikan agama meliputi penilaian hasil belajar oleh pendidik, satuan pendidikan dan pemerintah. Selanjutnya ayat 4 menjelaskan bahwa penilaian hasil belajar sebagaimana dimaksud pada ayat (1) dilakukan dalam bentuk ujian yang dilaksanakan secara nasional.

Tinggi rendahnya prestasi siswa khusus bidang agama Hindu dapat juga penulis kemukakan berdasarkan Nilai Ujian Sekolah Berstandar Nasional untuk kelas XII. Khusus materi agama Hindu, menunjukkan bahwa baru sekitar $70 \%$ siswa yang mencapai kreteria 
ketuntasan minimal (KKM) dari dari kreteria ketuntasan minimal (KKM) yaitu 75 yang di tetapkan. Hal ini menyebabkan sekitar 30\% siswa-siswi Hindu perlu meningkatkan pelaksanaan pembelajaran. Kenyataan ini menunjukkan bahwa sebenarnya masih perlu ada upaya-upaya yang harus dilaksanakan untuk meningkatkan hasil belajar siswa.

Didalam kelas rata-rata terdapat 5-8 siswa-siswi beragama Hindu yang dibimbing oleh seorang guru agama, memang secara klasikal itu bisa tetapi akan sangat sulit dalam membentuk watak dan karakter mereka menjadi lebih baik secara merata karena dalam kelas tersebut banyak terdapat pemikiran dan cara yang berbeda dari setiap individu/perseta didik dalam mengikuti pembelajaran khusunya pelajaran agama Hindu. Maka dari itu perlu adannya usaha ekstra dalam memperhatikan mereka dengan mengadakan pendampingan secara pribadi dan pendekatan secara persuasif. Sebab dalam penelitian ini akan di bahas mengenai "Faktor-Faktor yang mempengaruhiPendidikan Agama Hindu dalam menyikapi pelaksanaan Ujian Sekolah Berstandar Nasional (USBN) di SMA Negeri 2 Banama Tingang Kabupaten Pulang Pisau. Harapanya dari penelitian ini yaitu dapat mengungkapkan berbagi permasalahan dalam pembelajaran agama Hindu dan kesiapan pendidikan dan peserta didik dalam mengikuti Ujian Sekolah Berstandar Nasional Pendidikan Agama Hindu secara efektif.

\section{PEMBAHASAN}

\subsection{Pengertian Pendidikan Agama} Hindu

Agama merupakan kebutuhan dasar setiap manusia karena merupakan naluri yang terdalam dari setiap insan. Oleh sebab itu dalam kehidupan seharihari, khususnya seorang siswa seharusnya dibelakali pemahaman agama yang kokoh agar hidupnya terarah dengan baik. Pendidikan Agama Hindu adalah sebuah pendidikan dengansuatu upaya untuk membina pertumbuhan jiwa raga anak didik sesuai dengan ajaran agama Hindu.Pendidikan merupakan usaha sadar dan terencana untuk menyiapkan siswa dalam meyakini, memahami, menghayati dan mengamalkan melalui kegiatan bimbingan, pengajaran dan atau latihan. Hal itu juga dibarengi dengan tuntutan untuk menghormati penganut agama lain dalam hubungannya dengan kerukunan antar umat beragama hingga terwujud kesatuan dan persatuan bangsa. Pendidikan agama Hindu pada hakikatnya merupakan sebuah proses itu, dalam perkembangannya juga dimaksudkan sebagai tumpuan mata pelajaran yang diajarkan di sekolah maupun di luar sekolah secara informal ( Pasraman).

\subsubsection{Belajar}

Oemar Hamalik (2001 : 27 )

mengemukakan pengertian belajar adalah suatu proses perubahan tingkah laku individu melalui interaksi dengan lingkungan. Slameto (2003 : 2) berpendapat bahwa belajar ialah suatu proses usaha yang dilakukan seseorang untuk memperoleh suatu perubahan 
tingkah laku secara keseluruhan, sebagai hasil pengalamannya sendiri dalam interaksi dengan lingkungannya. Hal ini sesuai dengan pendapat Suparwoto (2004 : 41) bahwa belajar pada intinya adalah proses internalisasi dalam diri individu yang belajar dapat dikenali produk belajarnya yaitu berupa perubahan, baik penguasaan materi, tingkah laku, maupun keterampilan.

William

Burton

mengemukakan bahwa "A good learning situation consist of a rich and varied series of learning experiences unified around a vigorous purpose and carried on in interaction with a rich, varied and propocative environment". Yang berarti bahwa belajar adalah suatu proses perubahan tingkah laku individu melalui interaksi dengan lingkungan. Di dalam interaksi inilah terjadi serangkaian pengalaman - pengalaman belajar. Menurut Winkel belajar adalah semua aktivitas mental atau psikis yang berlangsung dalam interaksi aktif dalam lingkungan, yang menghasilkan perubahanperubahan dalam pengelolaan pemahaman. Menurut Ernest R. Hilgard belajar merupakan proses perbuatan yang dilakukan dengan sengaja, yang kemudian menimbulkan perubahan, yang keadaannya berbeda dari perubahan yang ditimbulkan oleh lainnya. Sifat perubahannya relatif permanen, tidak akan kembali kepada keadaan semula. Tidak bisa diterapkan pada perubahan akibat situasi sesaat, seperti perubahan akibat kelelahan, sakit, mabuk, dan sebagainya (Purwanto, 2008 : 51)

Sedangkan pengertian belajar menurut Gagne (Mulyani Sumantri \&
Johar Permana, 1999 : 16) belajar merupakan sejenis perubahan yang diperlihatkan dalam perubahan tingkah laku, yang keadaaannya berbeda dari sebelum individu berada dalam situasi belajar dan sesudah melakukan tindakan yang serupa itu. Perubahan terjadi akibat adanya suatu pengalaman atau latihan. Berbeda dengan perubahan serta-merta akibat refleks atau perilaku yang bersifat naluriah.

Moh. Surya dikutip oleh Nana Sudjana (2005 : 22) mendefinisikan belajar adalah suatu proses usaha yang dilakukan individu untuk memperoleh suatu perubahan tingkah laku yang baru keseluruhan, sebagai hasil pengalaman individu itu sendiri dalam interaksinya dengan lingkungan.

Oemar Hamalik (1993 : 280) mengungkapkan empat prinsip belajar yaitu :

a. Belajar senantiasa harus bertujuan, terarah, dan jelas bagi siswa, karena tujuan akan menuntut dalam belajar,

b. Jenis belajar yang paling utama adalah untuk berpikir kritis,

c. Belajar memerlukan pemahaman atas hal - hal yang dipelajari sehingga memperoleh pengertian pengertian,

d. Belajar harus disertai keinginan dan kemauan yang kuat untuk mencapai tujuan dan hasil.

Dari prinsip - prinsip tersebut memberikan penjelasan dalam memaknai belajar dan dapat mengetahui apa saja yang perlu diperhatikan dalam 
mendukung proses pembelajaran, sehingga pengertian dan pemahaman mengenai makna belajar menjadi lebih jelas dan terarah.

Dari pendapat para ahli diatas dapat disimpulkan bahwa di dalam belajar ada suatu perubahan tingkah laku dalam diri seseorang berupa pengetahuan, pemahaman, maupun sikap yang diperoleh melalui proses belajar. Perubahan tingkah laku yang diperoleh merupakan hasil interaksi dengan lingkungan. Interaksi tersebut salah satunya adalah proses pembelajaran yang diperoleh di sekolah. Oleh karena itu dapat dikatakan bahwa dengan belajar seseorang dapat memperoleh sesuatu yang baru baik itu pengetahuan, keterampilan maupun sikap.

\subsubsection{Hasil Belajar}

Menurut Nana Sudjana (2005 : 20) hakikat hasil belajar adalah perubahan tingkah laku individu yang mencakup aspek kognitif, afektif, dan psikomotorik. Menurut Nana Sudjana (2005 : 38) hasil belajar yang dicapai siswa dipengaruhi oleh dua faktor utama yakni faktor dari dalam diri siswa itu dan faktor yang datang dari luar diri siswa atau faktor lingkungan. Faktor yang datang dari diri siswa terutama kemampuan yang dimilikinya. Faktor kemampuan siswa besar sekali pengaruhnya terhadap hasil belajar yang dicapai. Disamping faktor kemampuan yang dimiliki siswa, juga ada faktor lain, seperti motivasi belajar, minat dan perhatian, sikap dan kebiasaan belajar, ketekunan, sosial ekonomi, faktor fisik dan psikis.
Dalam sistem pendidikan nasional rumusan tujuan pendiikan, baik tujuan kurikuler maupun tujuan instruksional, menggunakan hasil belajar dari Bloom (Purwanto, 2008 : 50) yang secara garis besar membaginya dalam tiga ranah yaitu ranah kognitif, ranah afektif dan ranah psikomotor.

\subsection{Faktor-faktor}

yang mempengaruhi Proses Pembelajaran Agama Hindu di SMA Negeri 2 Banama Tingang Kabupaten Pulang Pisau.

Rendahnya mutu pendidikan Nasional menurut Habibie (dalam Ruindungan, 1996:8) dari hasil penelitiaanya menyatakan bahwasistem pendidikan di Indonesia masih belum mampu memberikan ruang yang lebih luas bagi pengembang kemampuan kreatif, khususnya kreatifitas berpikir anak.

Fenomena diatas memberikan gambaran terhadap pendidikan di Indonesia betapa sulitnya untuk diselesaikan dengan segera membiarkan tanpa meberikan solusi penyelesaikan merupakan tidakan yang tidak bijaksana. Oleh karena itu untuk mengatasi fenomena di atas, salah satu cara yang bisa dilakukan adalah melakukan pengkajian secara mendalam terhadap persoalan-persoalan berdasarkan rujukan filisofis atau teori valid dan penelitian (Sanusi, 1998: 267)

Bab XIII, Pasal 31 Ayat UUD 1945 berbunyi: Negara memprioritaskan anggaran pendidikan sekurang-kurangnya dua puluh persen darianggaran pendapatan dan belanja 
negara serta dari anggaran pendapatan dan belanja daerahuntuk memenuhi kebutuhan penyelenggaraan pendidikan nasional. Dalam hal anggaran sebenarnya pemerintah Indonesia sudah sangat intens dalam memprioritaskan kebutuhan bagi dunia pendidikan di Indonesia baik itu sarana dan prasarana maupun gajih serta pemberian tunjangan sertifikasi guru guna kemajuan pendidikan di Indonesia.

Bab II Pasal 3 UU No. 20

Tahun 2003 Fungsi dan Tujuan Pendidikan. Pendidikan nasional berfungsi : Mengembangkan kemampuan dan membentuk watak serta peradaban bangsa yang bermartabat, dalam rangka mencerdaskan kehidupan bangsa; bertujuan untuk: berkembangnya potensi peserta didik agar menjadi insan yang beriman dan bertakwa kepada Tuhan Yang Maha Esa, berakhlak mulia, sehat, berilmu, cakap, kreatif, mandiri, dan menjadi warga negara yang demokratis serta bertanggung jawab. Paradigma ini sebenarnya sudah sangat didukung oleh PP Nomor 19 Tahun 2005 bab I ayat (6) Tentang standar proses. Proses pembelajaran harus dilaksanakan secara inspiratif, menyenangkan, menantang, memotivasi peserta didik untuk berpartisifasi aktif serta memberikan ruang yang cukup untuk mengembangkan kreativitas dan kemandirian sesuai dengan bakat dan minat peserta didik.

Institusi formal merupakan proses untuk mendapatkan ilmu pengetahuan, pendewasaan diri, pergaulan, pematangan pribadi, meperoleh serta membangun relasi dengan pribadi yang sama agar menjadi pribadi yang dewasa, berwawasan luas, berjiwa kesatrya, tidak kuper, plin-plan, berprinsip dan berintegritas yang tinggi. Dalam sistem pendidikan nasional rumusan tujuan pendidikan baik tujuan kurikuler maupun tujuan instruksional didasarkan pada klarifikasi hasil belajar. Menurut Taksonomi Bloom yang dikemukakan oleh Benyamin S.Bloom. Bloom membagi klarifikasi hasil belajar dalam tiga ranah atau bagian yaitu: (1) ranah kognitif, (2) ranah afektif, dan (3) ranah psikomotor.

Ranah kognitif perubahan
dimana siswa mengembangkan ketrampilannya, dan ranah afektif yaitu perubahan sikap oleh siswa terhadap pelajarannya yang diberikan pengembangan adalah ranah kognitif dan psikomotor ditandai dengan kemampuan dan ketrampilan yang dimiliki oleh siswa yang dimiliki sebelumnya. Terkait dengan tersebut, maka sudah merupakan suatu kewajaran pada setiap akhir proses belajar seorang mengalami perubahan pada dirinya. Perubahan itu terlihat dalam cara bertingkah laku yang baru, berkat pengalaman dan latihan dalam menjalani proses belajar. Sejauh mana seseorang mampu mencapai tujuan belajar dapat diketahui setelah dilakukan penilaian. Dengan penilaian yang dimaksudkan untuk mengetahui berhasil tidaknya seseorang dalam mencapai tujuan belajar, dan hasil belajar tersebut lazim disebut prestasi belajar. Prestasi belajar adalah taraf kemampuan untuk menguasai ilmu pengetahuan dan ketrampilan. Prestasi belajar dianggap hasil belajar, bukan 
saja sejumlah pengetahuan tetapi juga sejumlah ketrampilan kerja.

Gagne (dalam Dimyati dan Mudjiono, 1994: 9) dinyatakan bahwa: "prestasi belajar adalah berupa kapabilitas setelah orang memiliki ketrampilan pengetahuan sikap dan nalar". Menurut Nawawi (1981: 100) dinyatakan bahwa: "pengukuran terhadap kegiatan belajar yang telah dicapai dalam suatu pelajaran tertentu". Berdasarkan beberapa pendapat di atas dapat disimpulkan bahwa yang dimaksud dengan prestasi belajar adalah tingkat keberhasilan siswa dalam mempelajari materi pelajaran yang ditujukan dengan adanya perubahan tingkah laku berupa kapabilitas atau kemampuan siswa. Kapabilitas itu meliputi aspek kognitif, afektif, psikomotor atau ketrampilan siswa. Perubahan ini terjadi sebagai pengalaman dan hasil interaksi dengan lingkungan.

2.2.1 Faktor-faktor yang Mempengaruhi Belajar

Selain cara belajar ada faktorfaktor yang lain mempengaruhi belajar. Marilah kita tinjau faktor-faktor tersebut.

a. Kemampuan pembawaan

Kita ketahui bahwa tidak ada dua orang yang pembawaanya sama. Juga di dalam kemampuan tiap orang mempunyai potensi kemampuan sendiri-sendiri. Kemampuan pembawaan ini akan mempengaruhi belajarnya peserta didik. Peserta didik yang mempunyai kemampuan pembawaan yang lebih akan lebih mudah dan lebih cepat belajar dari pada peserta didik yang mempunyai kemampuan yang kurang. Tetapi di dalam hal ini kita tidak mengatakan bahwa kemampuan pembawaan ini adalah faktor yang paling penting atau faktor yang paling dominan dalam belajar. Kekurangan di dalam kemampuan pembawaan ini masih dapat diatasi dengan banyak cara, misalnya dengan membuat latihanlatihan yang banyak. Jadi faktor pembawaan ini hanyalah satu faktor dari belajar.

\section{b. Kondisi fisik orang yang belajar}

Orang yang belajar tidak terlepas dari kondisi phisiknya. Maka adanya anak yang sering sakit prestasinya menurun. Anak yang cacat misalnya kurang pendengaran, kurang penglihatan prestasinya juga kurang apabila dibandingkan dengan anak yang normal. Maka perlulah diperhatikan kondisi pisik anak yang belajar.

c. Kamauan belajar

Kemauan ini memegang peranan yang sangat penting di dalam belajar. Adanya kemauan dapat mendorong belajar dan sebaliknya tidak adanya kemauan dapat memperlemah belajar. Di dalam individu yang belajar harus ada dorongan dalam dirinya yang dapat mendorongnya ke suatu tujuan. Yang berarti kemauan belajar ini sangat erat hubungannya dengan keinginan dan tujuan individu. Ini berbeda dalam masing-masing individu, maka untuk memberi dorongan pada masing-masing orang berbeda-beda pula caranya. Untuk dapat memberi dorongan seseorang harus ditemukan: perhatiannya, latar belakangnya, 
kemampuannya dengan cara membuat hubungan pribadi. Apabila pendidikan sudah mendapatkan itu semua, maka dapatlah ia membuat pelajaran yang diberikan itu sedemikian rupa sehingga orang yang belajar merasa bahwa pelajaran itu sangat berarti baginya dan ia merasa bahwa ia dapat mencapainya, maka terbentuklah keinginan belajar (Mustaqim, dkk. 1991: 63).

Pembelajaran dapat diberi arti sebagai setiap upaya yang sistematik dan sengaja oleh pendidik untuk menciptakan kondisi agar peserta didik melakukan kegiatan belajar. Dalam kegiatan terjadi interaksi yang edukatif, yaitu antara peserta didik (siswa peserta larihan dan lain sebagainya) yang melakukan kegiatan belajar dengan pendidik (guru, pelatih, dan sebagainya) yang melakukan kegiatan membelajarkan. Di dalam proses pembelajaran diperlukan adanya upayaupaya pendidik untuk meningkatkan mutu pendidikan.

Terkait dengan hal tersebut, dalam proses pembelajaran harus tercipta suasana yang menggairahkan dan menantang. Ada beberapa hal yang dapat digunakan untuk meningkatkan mutu pendidikan tersebut diantaranya adalah pemilihan metode yang tepat yaitu: 1) metode ceramah, 2) metode tanya jawab, 3) metode kelompok, 4) penerapan model pembelajaran inquiri, 5) penerapan model Pembelajaran Cooperative Learning. Kegiatan belajar dan pembelajaran yang melahirkan interaksi unsur-unsur manusiawi adalah sebagai suatu proses dalam mencapai tujuan pembelajaran. Pengajar dengan sadar berusaha mengatur lingkungan belajar agar begariah bagi si pembelajar. Salah satu usaha guru dalam mengatur proses pembelajaran agar bergairah adalah memilih model yang tepat. Menentukan model mengajar yang dirasa tepat memanglah sulit. Oleh karena itu, guru dan juga siswa diharapkan memahami berbagai macam model belajar pembelajaran. Model mengajar yang akan digunakan sangat tergantung pada tujuan intruksional itu sendiri. Guru harus memandang mengajar sebagai suatu proses untuk menciptakan lingkungan yang baik sehingga terjadi belajar yang efektif dan efisien. Dalam hal ini siswa harus mampu mengatur dan menata seperangkat nilai-nilai dan kepercayaan yang mempengaruhi pandangan terhadap realitas sekelilingnya.

Suatu model yang dipilih, adalah model mengajar yang mampu mengungkapkan berbagai realitas yang sesuai dengan situasi kelas dan macam pandangan hidup yang dihasilkan atas kerjasama antara guru-guru dan siswa. Model mengajar yang merupakan hasil dari suatu pemilihan sebenarnya bukanlah model mengajar yang sempurna. Yang dapat memecahkan semua masalah pengajaran sehingga bukanlah dimaksudkan untuk melaksanakan berbagai gaya belajar siswa. Tindakan menentukan model mengajar di dalam suatu asumsi hanya ada model belajar tertentu yang sesuai untuk ditangani dengan model mengajar tertentu pula. Apabila guru menginginkan siswa menjadi produktif dan kreatif, guru harus memberi kesempatan yang seluas-luasnya bagi 
perkembangan siswa sesuai dengan gaya yang dimilikinya dan penerapan model mengajar harus disesuaikan dengan kebutuhan siswa (Sri Anitah Wirawan, dkk. 1992: 63).

\subsubsection{Faktor-faktor yang}

Mempengaruhi Prestasi Belajar

Prestasi belajar dipengaruhi oleh dua faktor utama yaitu: faktor yang datang dari dalam diri (faktor internal), dan faktor yang datang dari luar diri atau faktor lingkungan (faktor eksternal). Menurut pendapat Gone Lekas (dalam Tabrani dan Daryani, 1992: 22) dinyatakan bahwa: "hasil belajar seseorang dapat dipengaruhi oleh lima faktor yaitu: 1) bakat yang dimiliki, 2) waktu yang tersedia untuk belajar, 3) waktu yang diperlukan untuk belajar, 4) kwalitas pengajaran, dan 5) kemampuan individu dalam belajar".

Untuk lebih jelasnya akan diuraikan faktor-faktor tersebut sebagai berikut;

1. Faktor internal, faktor yang timbul dari dalam diri peserta didik, seperti:

a) Faktor biologis, yaitu kesehatan, badan yang sehat berarti tidak mengalami gangguan penyakit tertentu, cukup vitamin dan seluruh badan berfungsi dengan baik, sehingga mempengaruhi belajarnya.

b) Faktor minat mempengaruhi terhadap prestasi belajar. Tanpa minat sulit menimbulkan perhatian siswa terhadap pelajaran, sehingga dapat mempengaruhi prestasi belajar.

c) Faktor bakatnya, seringkali orang tua memaksakan supaya anaknya ke pola yang tidak sesuai dengan bakatnya, sehingga mengalami kesulitan belajarnya.

2. Faktor eksternal, faktor yang timbul dari luar diri sendiri, seperti:

a) Faktor orang tua yang sangat berpengaruh terhadap kemajuan prestasi anaknya. Kurangnya perhatian orang tua terhadap belajar anak-anaknya, kemudian terlalu memanjakan anak-anak berakibat pada fatalnya prestasi anak didik.

b) Faktor suasana rumah, suasana rumah yang terlalu ribut orang tua yang sering bertengkar dan kurang harmonis dalam keluarga akan berakibat patal pula terhadap prestasi belajar anak didik.

c) Faktor lingkungan, teman bermain anak didik dalam masyarakat yang kurang baik sangat besar pengaruhnya dalam pertumbuhan mental. Siswa tidak dapat menilai teman yang baik dan tidak dapat mengendalikan dirinya, dia akan terganggu prestasi belajarnya.

d) Faktor sekolah, sekolah merupakan lembaga formal pertama setelah keluarga yang bertugas mendidik serta mengarahkan anak untuk mengalami suatu perobahan sikap dan tingkah laku.

Dari penjelasan beberapa faktor diatas dapat dijelaskan bahwa: Kecerdasan dan keberhasilan seorang siswa sangat berpengaruh dari situasi dan keadaan beberapa faktor, semua hal tersebut dapat di dicapai dengan baik apabila seorang siswa mampu menghindari ataupun beradapatasi dan 
mampu memilah atau memilih kebiasaan dan kesalahan dari bebrapa hal yang mengakitbatkan proses belajar menjadi terganggu. Akan tetapi jika hal tersebut mampu diatasi maka dalam proses belajar sesulit apapun akan mampu teratasi dengan baik.

\subsection{Dampak dari pelaksanaan UjianSekolah Berstandar Nasional Agama Hindu bagi peserta didik di SMA Negeri 2 Banama Tingang.}

Dari hasil pengamatan peneliti pada saat ujian dilaksanakan (8-13 Mei 2017) di SMA Negeri 2 Banama Tingang dapat diperoleh dari pengamatan tersebut yaitu :

\subsubsection{Dampak Negatif}

Ujian Sekolah Berstandar Nasional tahun pelajaran 2016/2017 merupakan ujian akhir sekolah ditingkat sekolah menengah atas yang pertama dilaksanakan secara bersama di Indonesia khususnya mata pelajaran agama Hindu. Siswa kelas XII yang mengikuti Ujian Sekolah Berstandar Nasional (USBN) sebagian besar masih cenderung pasif dalam mengerjakan soal Agama Hindu. Siswa cenderung kompetitif dalam mengerjakan, artinya memiliki kemampuan akademis lebih tinggi, jarang bekerjasama dengan siswa yang kemampuan akademisnya rendah maupun yang memiliki kemampuan lebih tinggi. Proses pembentukan pengetahuan siswa jarang melalui proses menemukan sendiri dan juga kurang mengoptimalkan waktu ujian, masih melihat teman dalam menakar waktu, artinya jika temannya sudah banyak yang keluar waktu tidak menjadi pertimbangan dan jika soal sudah selesai dikerjakan peserta didik juga ikut keluar tanpa memperhatikan dan mengoreksi kembali hasil dari pada pekerjaannya apakah sudah benar ataupun salah, menyatakan dirinya sudah selesai mengerjakan soal-soal Ujian SekolahBerstandar Nasional(USBN) agama Hindu dengan benar padahal belum tentu semua soal yang sudah dikerjakan dinyatakan benar.

\subsubsection{Dampak Positif}

Dari hasil pengamatan Ujian Sekolah tanggal 8-13 Mei 2017 di SMA Negeri 2 Banama Tingang diperoleh hasil bahwa : siswa-siswi yang beragama Hindu dalam melaksanakan Ujian Sekolah Berstandar Nasional mereka datang lebih awal dari sekolah biasanya. Tidak ada waktu untuk bercanda, bermain dan bergurau selain mengoptimalkan waktu untuk belajar dan belajar. Dalam mengerjakan soalsoal ujian sekolah mereka sangat konsentrasi, segala jenis peralatan sekolah seperti pensil, pulpen dan papan alas jauh lebih siap dibandingan dengan sekolah seperti biasannya. Dirumahpun mereka tidak banyak bermain karena waktunya hanya dikhususkan untuk belajar dan belajar, hal lain juga dikarenakan pengawasan orang tua yang lebih ketat mengingat kegiatan ujian sekolah masih berjalan.

\subsubsection{Dampak Bagi Guru}

Penerapan ujian sekolah berstandar nasional dilaksanakan tentunya sangat berdampak bagi para guru agama khususnya guru agama Hindu di Kabupaten Pulang Pisau Provinsi Kalimantan Tengah. Sebab 
penerapan soal harus disesuaikan dengan kurikulum yang berlaku sesuai aturan dan standarisasi pendidikan nasional. Akan tetapi daerah juga diberikan kewenangan sebesar $25 \%$ dalam pembutan soal yang bermuatan lokal genius, budaya dan adat istiadat yang berlaku di daerah setempat sesuai dengan agama yang ada, guna untuk mengangkat keberagaman budaya yang sangat mendukung aktifitas keagamaan. Seperti : acara Tiwah yang bisa dimasukan ke dalam sub soal Pitra Yadnya, Mamapas Lewu yang bisa dimasukan ke dalam sub soal Bhuta Yadnya dan masih banyak lainnya yang bisa di angkat untuk mengembangkan kurikulum yang sudah ada sesuai standar nasional.

Dalam hal ini guru agama Hindu tentunya harus konsen terhadap pelaksanaan ujian ini. Mengingat soal yang dibuat harus disesuaikan dengan setandar yang sudah ditetapkan dan disesuaikan dengan kurikulum ataupun aturan yang berlaku. Persiapanpersiapan yang lebih ekstra tentunya sudah lebih awal dilakukan untuk mempersiapkan mengahadapi Ujian Sekolah Berstandar Nasional. Hal awal yang perlu dipersiapan yaitu: ketuntasan pembelajaran, Pembuatan kisi-kisi soal, pembahasan kisi-kisi soal yang telah disiapkan pusat, dan pembahasanpembahasan lain yang kiranya dapat mendukung ketuntasan pembelajaran dalam pembelajaran pendidikan agama Hindu.

Kelulusan peserta didik tetap menjadi prioritas dalam proses pembelajaran sebab, hasil kelulusan dan nilai dalam sebuah evalusi akan sangat mempengaruhi elekstabilitas sekolah. Apabila peserta didik 99\% lulus dengan nilai yang memuaskan tentu siap pendidik/guru merasa puas karena merasa berhasil dalam melaksanakan proses belajar mengajar, dan apabila dengan hasil yang terbalik dengan nilai yang tidak memuaskan tentu akan menjadi bomerang dan dinyatakan tidak tuntas dalam memberikan pembelajaran pada peserta didiknya. Dalam hal ini pelaksanaan Ujian Sekolah Berstandar di SMA Negeri 2 Banama Tingang tahun ajaran 2016/2017 memperoleh hasil cukup memuaskan, dengan berbagi catatan ketuntasan yang perlu dibenahi di tahun selanjutnya.

3.3.4 Dampak Bagi Sekolah

Akibat dari pelaksanaan ujian sekolah berstandar nasional juga sangat ditentukan oleh kepekaan warga sekolah, dalam hal ini adalah kepala sekolah yang mempersiapkan dan menghadapi pelaksanaan ujian tersebut. Apabila memperoleh nilai dan kelulusan yang bagus tentu nilai bagus ataupun predikat yang memuaskan akan diperoleh sekolah pelaksana, dan sebaliknya apabila nilai dan kelulusan yang telah menjadi target sekolah tidak tercapai, hal ini akan berdampak negatif bagi warga sekolah, bisa saja sekolah akan mendapat pinalti akibat ketidak berhasilan dalam mencapai target dan bisa juga akan berdampak negatif bagi guru,teruama kepala sekolah selaku pimpinan. Citra kegagalan akan berdampak sistemik dari guru ke kepala sekolah, dari kepala sekolah ke pengawas, dan tentunnya sangat berdampak bagi para pimpinan daerah yang bergerak dibidang pendidikan. 
Dalam pelaksanaan Ujian Sekoalah Berstandar Nasional di SMA Negeri 2 Banama Tingang dapat memberikan citra yang positif, dimana target yang direncanakan dapat dipeoleh sesuai dengan yang diharapkan. Walaupun ada beberapa catatan yang harus dipersiapkan lebih matang guna menghadapi pelaksanaan ujian selanjutnya.

\section{PENUTUP}

Keberhasilan seorang siswa sangat dipengaruhi dari berbagai faktor. Beberapa faktor yang sifatnya negatif tentunya harus dipelajari dan harus dipahami agar kemampuan dan kemauan belajar siswa semakin meningkat, sebab jika hal itu tidak dilaksanakan dengan benar, dan perhatian yang serius maka akan mengakibatkan dampak negatif bagi perkembangan dan kemampuan belajar siswa khususnya pelajaran agama Hindu. Faktor yang sifatnya positif, tentunya juga harus diperhatikan sebagai motivasi, evaluasi dan dukungan agar dapat menambah semangat belajar dan mengajar sehingga memberikan dampak yang positif dari hasil belajar yang telah tercapai serta adanya peningkatan hasil belajar dari jenjang selanjutnya.Mengingat kegiatan belajar mengajar tidak hanya cukup pada satu jenjang melainkan ada beberapa jenjang, begitu juga pada pembelajaran agama Hindu yang tersu membutuhkan kesinambungan secara terus menerus agar dapat mencetak sumber daya yang handal dibidangnya.

Keberhasilan mutlak pada pelakasanaan Ujian Sekolah Berstandar
Nasional adalah tertumpu pada kemauan siswa, kesiapan para guru, dan warga sekolah.Apabila siswa-siswi selalu konsen akan pentingnya kegiatan ujian sekolah tentunya harus memperhatikan beberapa kreteria yang harus dipersiapkan dalam menghadapi ujian sekolah, mengingat perkembangan materi pembelajaran khusunya pendidikan agama Hindu terus maju dan berkembang, mengikuti perkembangan yang ada sesuai dengan peraturan pemerintah dan standar pendidikan nasioanl, ditambah dengan pengayaan beberapa materi dan literatur guna mengikuti ketentuan pendidikan nasiaonal yang tertuang dalam Undangundang dan standar pendidikan nasional.

\section{DAFTAR PUSTAKA}

Tim Penyusun, 1994. Buku Pendidikan Agama Hindu Untuk Perguruan Tinggi, Jakarta: Hanuman Sakti.

Abdurrahman dan Bintoro.(2000). Memahami Dan Menangani Siswa Dengan Problema Belajar. Jakarta: Depdiknas

Aqib Zainal. (2006). Penelitian Tindakan Kelas. Bandung : Yrama Widya

BSNP. (2006). Panduan Penyusunan Kurikulum Tingkat Satuan Pendidikan. Jakarta : Depdiknas

Hidayati. (2002). Pendidikan Ilmu Pengetahuan di Sekolah Dasar. Yogyakarta : FIP. UNY

Kasihani Kasbolah.(1999). Penelitian Tindakan Kelas (PTK). Jakarta : Depdikbud

Martha Kaufelt. (2008). Wahai Para Guru, Ubahlah Cara 
Mengajarmu!. Jakarta : PT Indeks

Mulyani Sumantri \& Johar Permana. (1999). Strategi Belajar Mengajar. Jakarta : Depdiknas

Mulyasa. (2010). Penelitian Tindakan Sekolah. Bandung : Rosdakarya

Nana Sudjana.(2005). Penilaian Hasil Proses Belajar Mengajar. Bandung : Rosdakarya

Oemar Hamalik. (1993). Metode dan Kesulitan Belajar. Jakarta : Bumi Aksara

Oemar Hamalik.(2001). Proses Belajar Mengajar. Jakarta : Bumi Aksara

Ruindungan, M.G. (1996). Model Bimbingan Peningkatan Kualitas Siswa SMU (Studi Kuasi Eksperimental Upaya Bantuan Pengembangan Berpikir Kreatif dan Sikap Kreatif pada Siswa SMUK Dago Bandung. Disertasi pada PPS IKIP Bandung.

Slameto. (2003). Belajar Dan Factor Factor Yang Mempengaruhinya. Jakarta : PT Rineka Cipta

Sanusi, A.(1998). Pendidikan Alternatif: Menyentuh Arah Dasar Persoalan Pendidikan dan Kemasyarakatan. Bandung: PT. Grafindo Media Pratama

Sugiyanto. (2009). Model - Model Pembelajaran Inovatif. Surakarta : Yuma Pustaka

Suharsimi Arikunto, dkk. (2005). Penelitian Tindakan Kelas. Jakarta : Bumi aksara

Suharsimi Arikunto. (2002). Dasar Dasar Evaluasi Pendidikan. Jakarta : Bumi Aksara

Sukardi.(2003). Metodologi Penelitian Pendidikan Kompetensi Dan Praktiknya. Jakarta : Bumi Aksara
Sutrisno Hadi. (2000). Metodologi Research. Yogyakarta : Andi

Suyanto.(1997). Pedoman Pelaksanaan Pendidikan Tindakan Kelas. Yogyakarta : Depdikbud

Wijaya Kesumah dan Dedi Dwitagama. (2010). Mengenal Penelitian Tindakan Kelas. Jakarta : PT Indeks 